\title{
Production of monoclonal antibodies for detection of Vibrio harveyi
}

\author{
Wannipa Phianphak ${ }^{1}$, Sirirat Rengpipat ${ }^{1}$, Sombat Rukpratanporn ${ }^{2}$, \\ Siwaporn Longyant ${ }^{3}$, Parin Chaivisuthangkura ${ }^{3}$, Weerawan Sithigorngul ${ }^{3}$, \\ Paisarn Sithigorngul ${ }^{3, *}$
}

\begin{abstract}
${ }^{1}$ Biotechnology Program, and ${ }^{2}$ Marine Biotechnology Research Unit, National Center for Genetic Engineering and Biotechnology, Ministry of Science and Technology, Faculty of Science, Chulalongkorn University, Bangkok 10330, Thailand ${ }^{3}$ Department of Biology, Faculty of Science, Sukhumvit 23, Srinakharinwirot University, Bangkok 10110, Thailand
\end{abstract}

\begin{abstract}
Monoclonal antibodies (MAbs) against Vibrio harveyi were produced from mice immunized with heat-killed and SDS-mercaptoethanol-treated highly virulent $V$. harveyi 639. Fifteen MAbs were selected and sorted into 6 groups according to their specificity to various proteins of apparent molecular weight ranging from 8 to $49 \mathrm{kDa}$. Some antibodies were used for detection of $V$. harveyi at concentrations as low as $10^{4} \mathrm{CFU} \mathrm{ml}^{-1}$ using immunodot blots. Most of the selected MAbs did not show cross-reactivity to other Vibrio species and other Gram-negative bacteria tested. Only 1 MAb (VH39-4E) showed slight cross-reactivity to Aeromonas hydrophila. Another MAb (VH24-8H) bound lightly to $V$. harveyi 1526 but strongly to $V$. harveyi 639, allowing rapid differentiation. Two of the MAb groups were used to localize $V$. harveyi in tissues of infected black tiger shrimp Penaeus monodon by immunohistochemistry. This study demonstrates the versatility of a highly specific immunological tool for the detection of $V$. harveyi in aquaculture and opens the way for further development of convenient test kits.
\end{abstract}

KEY WORDS: Dot blot · Immunohistochemistry · Monoclonal antibody $\cdot$ Vibrio harveyi $\cdot$ Penaeus monodon · Western blot

\section{INTRODUCTION}

Vibrio harveyi is the major cause of luminous vibriosis in marine fish, mollusks and crustaceans worldwide (Egidius 1987, Austin \& Austin 1993, Diggles et al. 2000). It is commonly isolated from various habitats, including warm marine waters, surfaces of marine animals, light organs of certain marine fish and cephalopods, and intestines of aquatic animals (Baumann et al. 1971, Ramesh \& Venugopalan 1987, 1989). It has emerged as a serious pathogen of penaeid shrimp in hatcheries and farms in South America, Australia and SE Asia (La VillaPitogo et al. 1990, Jiravanichpaisal \& Miyazaki 1994, Pizzutto \& Hirst 1995, Liu et al. 1996a,b). V. harveyi comprises Gram-negative, motile rods with bipolar flagella. It is oxidase-positive and usually produces green colonies on thiosulphate citrate bile salt (TCBS) agar (Difco). V. harveyi is a facultative anaerobe, obligate fermentative and sensitive to the vibriostatic agent O/129 (Pizzutto \& Hirst 1995). In addition, it fails to utilize inositol, sorbitol and melibiose and is positive for lysine decarboxylase, ornithine decarboxylase and gelatinase activities (Liu et al. 1996b). High levels of organic matter, with salinity from 10 to $60 \mathrm{ppt}$, water temperatures from 25 to $32^{\circ} \mathrm{C}$, $\mathrm{pH}$ from 5 to 9 and dissolved oxygen from 0.5 to $7.8 \mathrm{mg} \mathrm{l}^{-1}$, enhance its growth. Slow growth is observed at low salinity (5 ppt) and high alkalinity ( $\mathrm{pH} 9.5$ ) and no growth occurs at high acidity ( $\mathrm{pH} 3$ ). No effects on the growth of $V$. harveyi were detected at different levels of ammonium, nitrite and nitrate. In contrast, high levels of phosphate (50 ppm) had a negative affect on growth (Kiriratnikom et al. 2000). 
Vibrio harveyi was identified as a cause of luminescent disease in black tiger shrimp from hatcheries or farms in Thailand (Jiravanichpaisal \& Miyazaki 1994). Therefore, development of reagents and methods for detection of $V$. harveyi in shrimp and rearing water have been the focus of recent research. Although several methods have been developed to isolate, detect and control $V$. harveyi (Liu et al. 1996b, Alvarez et al. 1998, Jory 1998, Moriarty 1998, Rengpipat et al. 1998, Kiriratnikom et al. 2000, Alcaide et al. 2001, Zorrilla et al. 2003), there is currently no simple, rapid and accurate technique suitable for routine use by microbiologists or shrimp farmers. A major limiting factor has been the lack of high-quality immunodiagnostic reagents.

The use of monoclonal antibodies (MAbs) to detect other bacteria is well-known (Okrend et al. 1990, Adam et al. 1995, He et al. 1996, Jaradat \& Zawistowski 1996, Saha \& Nair 1997, Charni et al. 2000, Rivera-Betancourt \& Keen 2000, Jung et al. 2001). Munro et al. (2003) produced MAbs specific to an exotoxin from Vibrio harveyi Strain 642. However, the assay (Western blot analysis) was not highly sensitive and could not be easily applied during field examinations. Polyclonal antibodies against $V$. harveyi antigens were produced by Lee et al. (1997b), but crossreactivity was observed amongst species. Therefore, the production of MAbs against unique antigens or epitopes of $V$. harveyi would be a logical first step to develop specific immunodiagnostic tests. MAbs could be produced in an unlimited supply through cell culture techniques (He et al. 1996, Quinlan \& Foegeding 1997).

In the present study, MAbs specific to Vibrio harveyi were produced and used to examine antigenic differences among various strains and to locate $V$. harveyi by immunohistochemistry in tissue sections of infected Penaeus monodon. suspension was heat-killed at $60^{\circ} \mathrm{C}$ for $60 \mathrm{~min}$, then cooled to $4^{\circ} \mathrm{C}$. Part of the heated-killed antigen was further denatured by addition of $4 \%$ SDS, $10 \%$ mercaptoethanol at a ratio of 1:1 (v/v) and dialyzed against 3 changes of PBS at $6 \mathrm{~h}$ intervals. Both heat-killed and SDS-mercaptoethanol-treated bacteria were used for immunization.

Shrimp. Twenty Penaeus monodon $30 \mathrm{~d}$ post-larvae (PL 30) were maintained in fiberglass tanks supplied with flow-through seawater (20 ppt) at room temperature. They were injected $\left(50 \mu \mathrm{l}\right.$ shrimp $\left.{ }^{-1}\right)$ with a suspension of Vibrio harveyi 639 at approximately $10^{9} \mathrm{CFU} \mathrm{ml}{ }^{-1}$ through the arthrodial membrane of the second walking leg. When the injected shrimp showed signs of feeding cessation, slow movement or death, an organ was aseptically removed for isolation of $V$. harveyi 639. Cephalothoraces from moribund shrimp were also collected and fixed in Davidson's fixative (Lightner 1996) in preparation for immunohistochemistry studies. Cephalothoraces from non-injected shrimp were prepared in the same manner for the negative control.

Immunization. Four Swiss mice were injected intraperitoneally with heat-killed and SDS-mercaptoethanol-treated Vibrio harveyi 639 mixed with complete Freund's adjuvant at a 1:1 ratio. Mice were subsequently injected 3 more times with the treated bacteria mixed with incomplete Freund's adjuvant at 2 wk intervals. One wk after the fourth injection, mouse antisera were collected and tested against heatkilled and SDS-mercaptoethanol-treated $V$. harveyi using dot-blot assays and Western blot (Sithigorngul et al. 2000). The best performing mouse was later boosted $3 \mathrm{~d}$ before hybridoma production.

Hybridoma production. A cell fusion procedure was adapted from the method developed by Köhler \& Milstein $(1975,1976)$ with modifications described by Mosmann et al. (1979). A P3X myeloma cell line was

\section{MATERIALS AND METHODS}

Bacterial culture and antigen preparation. Bacteria (Table 1) were cultured for $24 \mathrm{~h}$ at $30^{\circ} \mathrm{C}$ with shaking in tryptic soy broth (TSB). TSB was supplemented with $2 \% \mathrm{NaCl}(\mathrm{w} / \mathrm{v})$ for the growth of Vibrio and Photobacterium species. Solid media were made by the addition of agar $1.5 \%$. Bacteria were harvested by centrifugation $\left(4^{\circ} \mathrm{C}, 20 \mathrm{~min}, 3000 \times \mathrm{g}\right)$ and suspended in $0.15 \mathrm{M}$ phosphate-buffered saline (PBS) pH 7.2 to a density of $2 \times 10^{9}$ colony-forming units (CFU) $\mathrm{ml}^{-1}$ (Lee et al. 1997b). For antigen preparation, the
Table 1. Bacteria used in the characterization of the monoclonal antibodies (MAbs). Vibrio harveyi was isolated in Thailand from Penaeus monodon showing signs of luminous vibriosis

\begin{tabular}{|ll|}
\hline Bacteria tested & Source \\
\hline Vibrio harveyi 639, 1526, VG, VG1 & CENTEX Shrimp, Thailand \\
V. alginolyticus & Department of Microbiology, \\
V. parahaemolyticus AQ 453 & Faculty of Science, Chulalongkorn \\
V. vulnificus & University, Thailand \\
V. mimicus & \\
& \\
Gram-negative bacteria: & Thailand Institute Science and \\
Aeromonas hydrophila & Technology Research, Thailand \\
Escherichia coli & \\
Photobacterium damselae & \\
Salmonella Typhimurium & \\
\hline
\end{tabular}


used as the fusion partner. Fusion products from 1 mouse were plated on 40 microculture plates (96 wells per plate). After identification of positive cultures by screening methods described in 'Dot-blotting' below, cells were cloned by the limiting dilution method and stored in liquid nitrogen.

Dot-blotting. Vibrio harveyi 639 in both heat-killed and SDS-mercaptoethanol-treated forms were used for screening. $V$. harveyi samples $\left(1 \mu \mathrm{l} \mathrm{spot}^{-1}\right)$ were applied to a nitrocellulose membrane, baked at $60^{\circ} \mathrm{C}$ for $10 \mathrm{~min}$, and incubated in hybridoma-conditioned medium from each culture $(1: 20$ dilution in $5 \%$ Blotto:5\% nonfat drymilk, 0.1\% Triton-X-100 in PBS) for $8 \mathrm{~h}$. After extensive washing in $0.5 \%$ Blotto, the membrane was incubated in horseradish peroxidase labelled goat anti-mouse gamma immunoglobulin heavy and light chain-specific (GAM-HRP, Bio-Rad) antibody at 1:1000 dilution for $8 \mathrm{~h}$. The membrane was then washed for $5 \mathrm{~min}$ in Blotto and incubated in a substrate mixture containing $0.03 \%$ diaminobenzidine (DAB), $0.006 \%$ hydrogen peroxide, and $0.05 \%$ cobalt chloride in PBS (Sithigorngul et al. 2000). Hybridoma cultures that displayed immunoreactivity against $V$. harveyi, but not against other bacteria, were confirmed for bacterial specificity by Western blot and immunohistochemistry before cloning and cryopreserving for further investigation.

SDS-PAGE and Western blot analysis. Vibrio harveyi and other bacterial proteins were separated by $15 \%$ SDS-PAGE according to the method described by Laemmli (1970). Samples were electrophoresed for $6 \mathrm{~h}$ at $30 \mathrm{~V}$ and gels were stained using Coomassie brilliant blue R-250. For Western blotting, samples resolved by SDS-PAGE were electro-blotted onto nitrocellulose membranes using a Transblot apparatus (Bio-Rad). The nitrocellulose membrane was incubated in 5\% Blotto for $10 \mathrm{~min}$, treated with 1:200 hybridoma-conditioned medium for $4 \mathrm{~h}$ and then processed as described above in the 'Dot-blotting' section. Low molecular weight markers (Bio-Rad) were used as standards. The reactivities of the MAbs with different isolates of $V$. harveyi and other bacterial species were tested by dot-blotting and by Western blot analysis.

Immunohistochemistry. Cephalothoraces of uninfected shrimp and Vibrio harveyi 639-infected shrimp were cut and fixed in Davidson's fixative solution for $24 \mathrm{~h}$ then processed for paraffin sectioning. Serial sections ( $8 \mu \mathrm{m}$ thickness) were prepared and processed for indirect immunoperoxidase staining using various MAbs and GAM-HRP diluted to 1:1000 with 10\% calf serum in PBS. Peroxidase activity was revealed by incubation with $0.03 \%$ DAB and $0.006 \% \mathrm{H}_{2} \mathrm{O}_{2}$ in PBS. Preparations were counter-stained with hematoxylin and eosin Y (H\&E), dehydrated in a graded ethanol series, cleared in xylene and mounted in permount
(Sithigorngul et al. 2000, 2002). Positive reactions were visualized as brown coloration against the pink and purple of H\&E.

Class and subclass determination. Class and subclass of mouse immunoglobulins produced by the hybridomas were determined by sandwich ELISA using Zymed's Mouse MonoAb ID Kit (HRP).

Sensitivity of MAb for Vibrio harveyi detection by dot-blot. Serial dilution of $V$. harveyi $639\left(10^{8} \mathrm{CFU}\right.$ $\mathrm{ml}^{-1}$ ) in PBS was performed and $1 \mu \mathrm{l}$ of each dilution was spotted onto a nitrocellulose membrane before fixing in $10 \%$ formalin for $30 \mathrm{~min}$ and processing for dotblot using various MAbs as described above. The lowest bacterial dilution that showed distinct and clear immunoreactivity was determined.

\section{RESULTS}

Mouse anti-Vibrio harveyi 639 antisera were collected from 4 mice and preabsorped with V. parahaemolyticus. All antisera showed specific binding to all $V$. harveyi isolates and no cross-reactivity to Vibrio species and other bacteria tested (Fig. 1 Panel 7, \& Fig. 2 Panel 7). Therefore, only 1 mouse was used as a spleen donor.

One fusion trial with 40 microculture plates yielded approximately 2500 culture wells, each containing 1 to 3 colonies of hybridoma cells. The first screening by dot-blot revealed 75 hybridoma cultures that yielded strong reactions with Vibrio harveyi 639 (Fig. 1). After screening by Western blot and dot-blot against various bacteria including several Vibrio species, 15 clones specific to $V$. harveyi were successfully established as permanent cell lines. Most antibodies specifically recognized $V$. harveyi and showed no cross-reactivity to other Vibrio species and other Gram-negative bacteria tested (Fig. 1, Table 1). An exception was MAb VH39$4 \mathrm{E}$, which showed slight cross-reactivity to Aeromonas hydrophila (Fig. 1 Panel 4, \& Fig. 2 Panel 4, Table 2). The cloned cell lines could be sorted into 6 types according to their specificities to bacterial proteins as determined by Western blot (Table 2, Fig. 2).

The first MAb type (3 clones) recognized a $49 \mathrm{kDa}$ protein. The second MAb type (4 clones) recognized 37 and $32 \mathrm{kDa}$ proteins. By immunohistochemistry, these antibodies could be used to localize Vibrio harveyi 639 in various tissues such as the lymphoid organ, hepatopancreas, heart, testis and muscle of infected Penaeus monodon (Figs. $3 \& 4$ ). The third MAb type (1 clone) also recognized 37 and $32 \mathrm{kDa}$ proteins but its immunohistochemistry reactions differed from those of Type 2 MAb in that positive signals occurred in different regions of the lymphoid organ and appeared as small condensed particles only in cells with condensed 
A B C

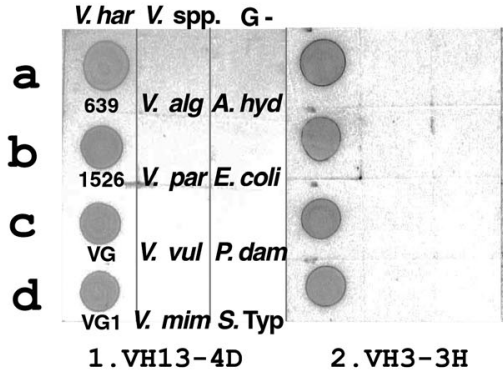

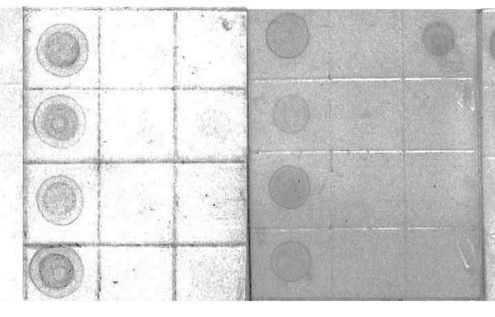

3. VH16-2A

4. VH39-4E

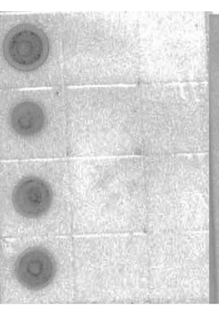

5. VH24-8H
A B C

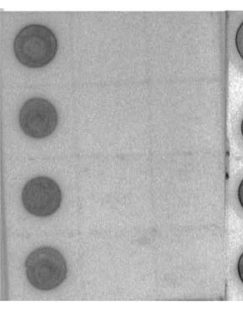

6. VH29-6D

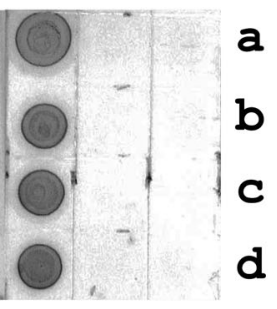

7. PAb

Fig. 1. Dot-blot analysis. Various bacteria $\left(10^{8} \mathrm{CFU} \mathrm{ml}^{-1}\right)$ were spotted on a nitrocellulose membrane $\left(1 \mu \mathrm{l}\right.$ spot $\left.{ }^{-1}\right)$ and treated with representatives of Type 1 to 6 MAbs and with mouse anti-Vibrio harveyi 639 antiserum (7.PAb) absorbed with V. parahaemolyticus. Each bacterium was spotted into each block of 3 columns as follows: Column A: (Row a) V. harveyi 639, (Row b) V. harveyi 1526, (Row c) V. harveyi VG, and (Row d) V. harveyi VG1; Column B: (Row a) V. alginolyticus, (Row b) V. parahaemolyticus, (Row c) V. vulnificus, and (Row d) V. mimicus; Column C: (Row a) Aeromonas hydrophila, (Row b) Escherichia coli, (Row c) Photobacterium damselae, and (Row d) Salmonella Typhimurium

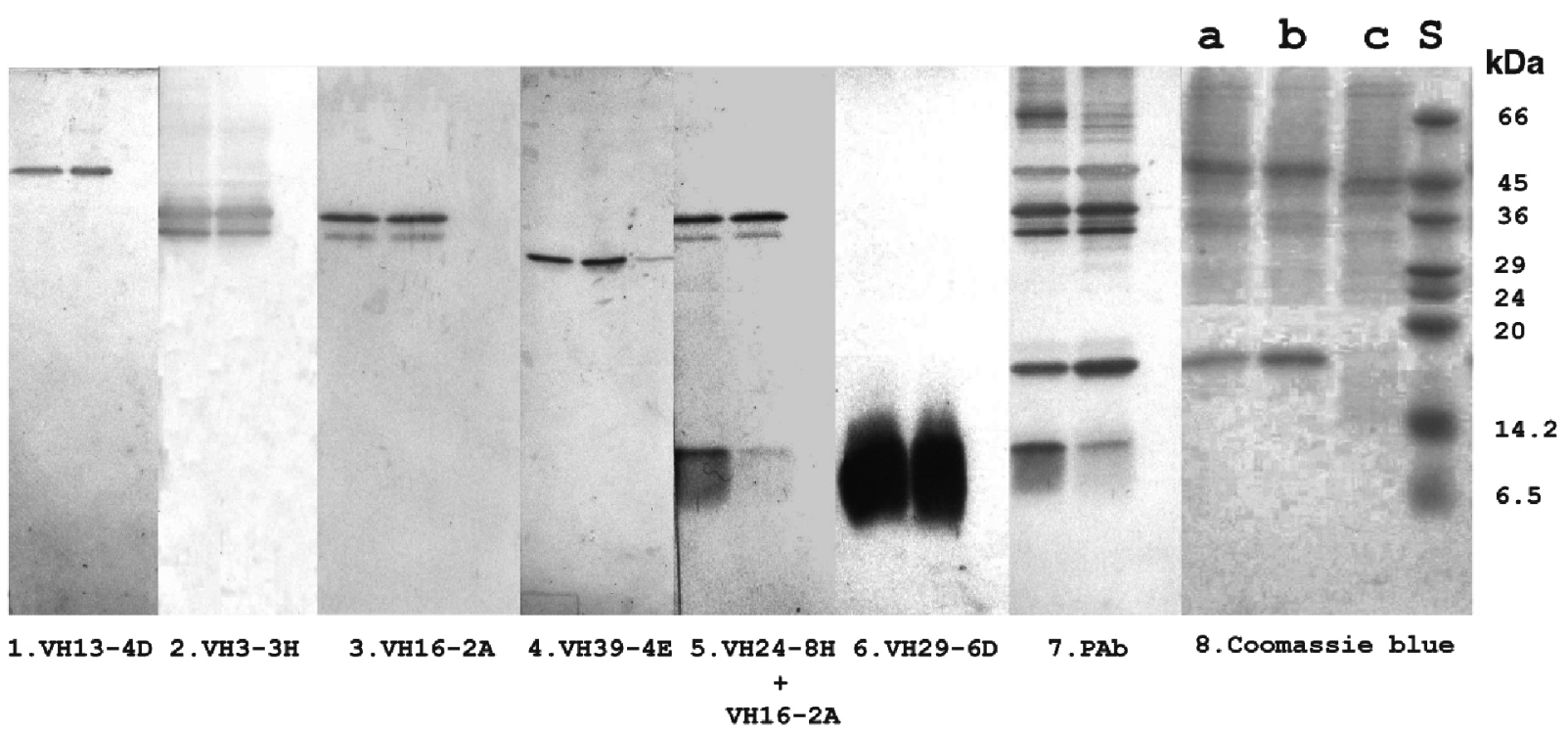

Fig. 2. Western blot and SDS-PAGE. Three bacteria-(a) Vibrio harveyi 639, (b) V. harveyi 1526, and (c) Aeromonas hydrophila $\left(\sim 10^{6} \mathrm{CFU}\right.$ lane $\left.{ }^{-1}\right)$ - were electrophoresed and stained with Coomassie blue (8) or transferred to a nitrocellulose membrane and then treated with representatives of Type 1 to 6 MAbs or with mouse anti- $V$. harveyi antiserum absorbed with $V$. parahaemolyticus (7). $\mathrm{S}=$ standard proteins (number denotes $\mathrm{kDa}$ ). Nitrocellulose membrane in Panel 5 was first treated with $\mathrm{MAb} \mathrm{VH} 24-8 \mathrm{H}$ then reprobed with MAb VH 16-2A to confirm the presence of equivalent amounts of antigens of $V$. harveyi 1526

nuclei (Fig. 3b,d). The fourth MAb type (1 clone) recognized a $22 \mathrm{kDa}$ protein and showed slight cross-reactivity to Aeromonas hydrophila. The fifth MAb type (1 clone) recognized a sharp protein band of $8 \mathrm{kDa}$ and bound only lightly to another virulent isolate of V. harveyi 1526 (Fig. 2 Panel 5). The sixth MAb type (5 clones) recognized a broad protein band around $8 \mathrm{kDa}$. These antibodies detected $V$. harveyi in dot-blot assays with different sensitivities ranging from $10^{4}$ to $10^{8} \mathrm{CFU} \mathrm{ml} \mathrm{m}^{-1}$ (Table 2) and Type 6 MAbs gave the highest sensitivity (Fig. 2 Panel 6). Classes and subclasses of MAb obtained were $\operatorname{IgG}_{1}, \operatorname{IgG}_{2} \mathrm{a}, \operatorname{IgG}_{2} \mathrm{~b}$ and $\operatorname{IgG}_{3}$ (Table 2).

\section{DISCUSSION}

It was surprising that Type 2 and 3 MAbs recognized the same proteins ( 37 and $32 \mathrm{kDa}$ ) but gave different immunohistochemical reactions. The observed differences could have occurred due to different epitope targets. Since the Type 2 MAb (VH3-3H) gave strong immunoreactivity in dot-blots of heat-killed (Fig. 1 Panel 2) and intact Vibrio harveyi (not shown), it may have recognized an exposed epitope. In contrast, the Type 3 MAb (VH16-2A) bound loosely to relatively intact bacteria in dot-blots but strongly to protein in Western blots. It also bound strongly to particulate 
Table 2. Specificity and threshold detection of MAbs tested by dot-blot, Western blot and immunohistochemistry. Underlined clones are representative MAbs used in various tests. +: strong immunoreactivity; -: no immunoreactivity

\begin{tabular}{|c|c|c|c|c|c|}
\hline Group & MAbs (type) & $\begin{array}{l}\text { Dot-blot } \\
\left.(\mathrm{CFU} \mathrm{ml})^{-1}\right)\end{array}$ & $\begin{array}{l}\text { Western blot } \\
\quad(\mathrm{kDa})\end{array}$ & $\begin{array}{l}\text { Immuno- } \\
\text { histo- } \\
\text { chemistry }\end{array}$ & Remarks \\
\hline 1 & $\begin{array}{l}\frac{\mathrm{VH} 13-4 \mathrm{D}}{\mathrm{VH}}\left(\mathrm{IgG}_{14}\right) \\
\text {-10G, VH25-8B (IgM) }\end{array}$ & $\sim 5 \times 10^{5}$ & 49 & - & \\
\hline 2 & $\begin{array}{l}\text { VH27-3G }\left(\operatorname{IgG}_{1}\right), \\
\text { VH3-3H, VH28-3B, } \\
\text { VH38-2D }\left(\operatorname{IgG}_{2} \mathrm{a}\right)\end{array}$ & $\sim 5 \times 10^{5}$ & 37,32 & + & Bound to unprocessed antigens \\
\hline 3 & $\underline{\mathrm{VH} 16-2 \mathrm{~A}}\left(\operatorname{IgG}_{2} \mathrm{a}\right)$ & $\sim 1 \times 10^{8}$ & 37,32 & + & Bound to processed antigens \\
\hline 4 & $\underline{\mathrm{VH}} 39-4 \mathrm{E}\left(\mathrm{IgG}_{2} \mathrm{~b}\right)$ & $\sim 1 \times 10^{6}$ & 22 & - & $\begin{array}{l}\text { Slight cross-reactivity to Aeromonas } \\
\text { hydrophila }\end{array}$ \\
\hline 5 & $\underline{\mathrm{VH}} 24-8 \mathrm{H}\left(\mathrm{IgG}_{2} \mathrm{a}\right)$ & $\sim 5 \times 10^{5}$ & 8 & - & Bound loosely to Vibrio harveyi 1526 \\
\hline 6 & $\begin{array}{l}\text { VH2-3B, VH2-6A, } \\
\text { VH21-10G }\left(\mathrm{IgG}_{3}\right), \mathrm{VH} 28-8 \mathrm{D}, \\
\text { VH29-6D }\left(\mathrm{IgG}_{1}\right)\end{array}$ & $\sim 1 \times 10^{4}$ & $\sim 8$ & - & $\begin{array}{l}\text { Different band from } \\
\text { VH24-8H antibody }\end{array}$ \\
\hline
\end{tabular}
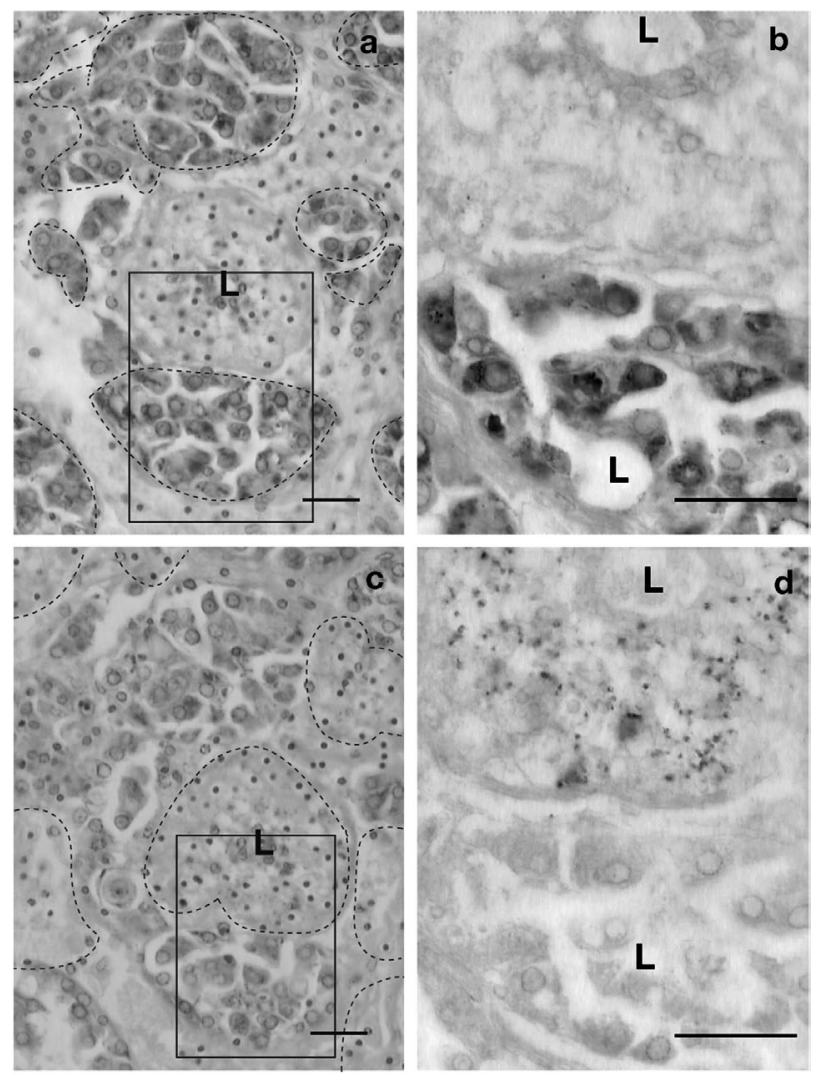

Fig. 3. Immunohistochemical detection of Vibrio harveyi infection in Penaeus monodon lymphoid organ. Four consecutive sections from $P$. monodon injected with $V$. harveyi 639 at $3 \mathrm{~h}$ were treated with MAbs $(\mathrm{a}, \mathrm{b}) \mathrm{VH} 3-3 \mathrm{H}$ or $(\mathrm{c}, \mathrm{d}) \mathrm{VH} 16-2 \mathrm{~A}$ and then counter-stained with $(\mathrm{a}, \mathrm{c})$ hematoxylin and eosin $\mathrm{Y}$ or (b,d) only eosin. Panels (b) and (d) show higher magnifications of the region in the rectangular frames in Panels (a) and (c). Immunoreactivity of the 2 MAbs occurred in different regions of the lymphoid tubules (areas surrounded by dotted lines). $\mathrm{L}=$ lumen of lymphoid tubule. Scale bars $=25 \mu \mathrm{m}$ material only in lymphoid organ cells with condensed nuclei or in a few hemocytes. This evidence suggested that it recognized a hidden epitope that became exposed after denaturation during Western blot preparation or after partial digestion in phagocytic cells. These 2 groups of antibodies may be useful for diagnosis of $V$. harveyi infection and for the study of immune mechanisms against $V$. harveyi in various organisms. The use of MAbs to follow antigen in various tissues such as the gut, kidney and spleen after oral vaccination has been demonstrated successfully with Aeromonas hydrophila in several species of carp (Azad et al. 2000). MAb immunohistochemistry has also been used to follow Photobacterium damselae ssp. piscicida infection in kidney, spleen and liver of sea bass (Jung et al. 2001).

Because of their high sensitivity (i.e. down to $10^{4}$ CFU ml ${ }^{-1}$ or $\sim 10$ cells spot $^{-1}$ ), Type 6 MAbs seemed to be the most suitable for further development of diagnostic techniques in aquaculture and in aquatic habitats. Combination with enrichment methods in specific selective media could augment the detection of Vibrio harveyi in the environment. For example, MAbs specific to Cytophaga johnsonae, Comamonas acidovorans and Aeromonas hydrophila have been used for identification, quantification and study of depth distribution in a lake (Faude \& Höfle 1997).

Given our results of no cross-reactivity with 4 closely related Vibrio species and with several other Gram-negative bacteria, it is unlikely that most of the developed MAbs will cross-react with other bacteria. Since MAbs are most likely to cross-react with antigens from closely related bacteria, the cross-reactivity of VH39-4E with Aeromonas hydrophilla but not with 4 other Vibrio species tested was perhaps 

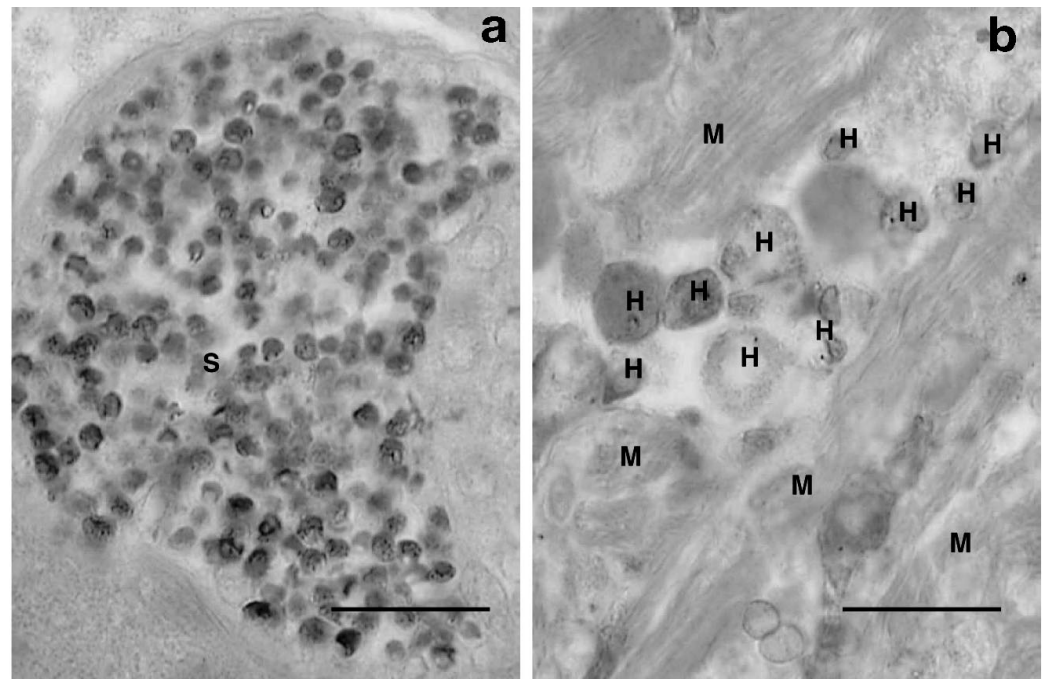

Fig. 4. Immunohistochemical detection of Vibrio harveyi infection in Penaeus monodon (a) testis and (b) heart. Sections from P. monodon infected with $V$. harveyi 639 at $3 \mathrm{~h}$ were treated with MAb VH3-3H and counter-stained with hematoxylin and eosin Y. Sections were from the same block shown in Fig. 3. Immunoreactivity was observed in both sperm (S), cardiac muscle (M) and hemocytes $(\mathrm{H})$. Scale bars $=25 \mu \mathrm{m}$

curious. On the other hand, both Vibrio and Aeromonas species are included in the family Vibrionaceae based on small-subunit rRNA sequences (Krieg \& Holt 1984) and it is possible that they may share some similar proteins. MAbs against Non-01 heat-stable enterotoxin of $V$. cholerae cross-reacted with antigens from $V$. mimicus and Yersinia enterocolitica (Takeda et al. 1990). MAbs against nonmembrane-damaging cytotoxin from $V$. cholerae $\mathrm{O} 26$ cross-reacted with antigens from $V$. parahaematolyticus, Aeromonas species and Shigella species (Saha \& Nair 1997). MAbs against lipopolysaccharide of Escherichia coli O26 cross-reacted with antigens of E. coli 0111 and Salmonella O35 (Rivera-Betancourt \& Keen 2000) and MAbs against Bacillus cereus cross-reacted with antigens from Bacillus thuringiensis (Charni et al. 2000).

Although we did not identify the antigen targets for our MAb, many potential antigens have been reported from Vibrio harveyi; these include O-polysaccharide antigen $(\mathrm{O}-\mathrm{Ag})$, flagella protein antigen $(\mathrm{H}-\mathrm{Ag})$ and extracellular products (ECPs) (Liu et al. 1996a,b) including proteases, hemolysins and cytotoxins that allow the bacteria to survive and replicate within host tissues (Ellis 1991). We demonstrated intracellular $V$. harveyi in many cell types by immunohistochemical localization using Type 2 MAb (VH3-3H). Proteases, phospholipases, hemolysins or exotoxins (ECPs) may play roles in the pathogenicity of $V$. harveyi in black tiger shrimp Penaeus monodon (Liu et al. 1996a,b, 1997, Lee et al. 1997a).
Our Type 1 MAbs recognized a $49 \mathrm{kDa}$ protein and Fukasawa et al. $(1988 a, b)$ have reported the presence of 3 metal chelator-sensitive proteases in ECPs produced from aquatic isolates of Vibrio harveyi with molecular weights of 84,49 and $46 \mathrm{kDa}$. They suggested that these molecules are major products of $V$. harveyi. Our Type 2 and 3 MAbs recognized 37 and $32 \mathrm{kDa}$ proteins. Zhang et al. (2001) found 2 closely related hemolysin genes designated vhhA and $v h h B$ encoding $47.3 \mathrm{kDa}$ proteins in $V$. harveyi VIB 645 that caused severe hemorrhagic septicemia in salmonids. The majority of other strains examined carried only a single hemolysin gene. Since our paired proteins are smaller, they may not be double bands of hemolysin, but they obviously share epitopes and may arise from closely related genes as in the hemolysin example. Our Type 5 and 6 MAbs recognized proteins in the range of $8 \mathrm{kDa}$. We cannot speculate on the nature of the sharp band obtained with Type $5 \mathrm{MAb}$ and the reason for the difference in strength of reaction between $V$. harveyi 1526 and $V$. harveyi 639. This could be explained by differences in recognized epitope or expression levels of the same protein. However, the broad reaction band for Type 6 MAbs was suggestive of reaction with lipopolysaccharides. In Photobacterium damselae ssp. piscicida, 2 MAbs have been reported that recognize a low molecular weight material running at the dye front and are believed to be lipopolysaccharides (Jung et al. 2001).

Lee et al. (1997b) demonstrated successful protection of Penaeus monodon against vibriosis by passive immunization using antisera against Vibrio harveyi antigens. However, the specificity of the antisera was not characterized. Broad-range detection was possible because of cross-reactivity between species and the use of a polyclonal antibody. MAbs against $V$. harveyi exotoxin subunits $(58,48,47,46,45,39 \mathrm{kDa})$ have been reported (Munro et al. 2003), but their cross-reactivity and ability for protection was not tested. Further, we cannot speculate whether our MAb would be protective.

MAbs can be used as a very specific immunological tool to accurately differentiate Vibrio harveyi from other Vibrio species and other bacteria and may be suitable for replacement of laborious and timeconsuming biochemical identifications. Further development of a very sensitive assay such as sandwich ELISA would facilitate the identification and quantitative analysis of vibriosis. 
Acknowledgements. This work was supported by the National Research Council, Thailand, and Thailand Research Fund, The Royal Golden Jubilee PhD Program, to W.P., who deeply appreciates the generous provision of bacterial samples for this study from CENTEX Shrimp, Thailand and Thailand Institute Science and Technology Research (TISTR), Thailand.

\section{LITERATURE CITED}

Adam A, Thompson KD, Morris D, Farias C, Chen SC (1995) Development and use of monoclonal antibody probes for immunohistochemistry, ELISA and IFAT to detect bacterial and parasitic fish pathogen. Fish Shellfish Immunol 5: $537-547$

Alcaide E, Gil-Sanz C, Sanjuan E, Esteve D, Amaro C, Silveira L (2001) Vibrio harveyi cause disease in seahorse, Hippocampus sp. J Fish Dis 24:311-313

Alvarez JD, Austin B, Alvarez AM, Reyes H (1998) Vibrio harveyi: a pathogen of penaeid shrimps and fish in Venezuela. J Fish Dis 21:313-316

Austin B, Austin DA (1993) Bacterial fish pathogen, 2nd edn. Ellis Horwood, Chichester, p 265-307

Azad IS, Shankar KM, Mohan CV, Kalita B (2000) Uptake and processing of biofilm and free-cell vaccines of Aeromonas hydrophila in Indian major carps and common carp following oral vaccination antigen localization by a monoclonal antibody. Dis Aquat Org 43:103-108

Baumann P, Baumann L, Mandel M (1971) Taxonomy of marine bacteria: the genus Beneckea. J Bacteriol 107: 268-294

Charni N, Perissol C, Petit JL, Rugani N (2000) Production and characterization of monoclonal antibodies against vegetative cells of Bacillus cereus. Appl Environ Microbiol 66:2278-2281

Diggles BK, Moss GA, Carson J, Anderson CD (2000) Luminous vibriosis in rock lobster Jasus verreauxi (Decapoda: Palinuridae) phyllosoma larvae associated with infection by Vibrio harveyi. Dis Aquat Org 43:127-137

Egidius E (1987) Vibriosis: pathogenicity and pathology: a review. Aquaculture 67:15-28

Ellis AE (1991) An appraisal of the extracellular toxins of Aeromonas salmonicida. J Fish Dis 14:265-277

Faude UC, Höfle MG (1997) Development and application of monoclonal antibodies for in situ detection of indigenous bacterial strains in aquatic ecosystems. Appl Environ Microbiol 63:4534-4542

Fukasawa S, Nakamura K, Kamii A, Ohyama Y, Osumi M (1988a) Purification and properties of a proteinase from a marine luminous bacterium, Vibrio harveyi strain FLA-11. Agric Biol Chem 52:435-441

Fukasawa S, Nakamura K, Miyahira M, Kurata M (1988b) Some properties of two proteinases from a luminous bacterium, Vibrio harveyi strain FLN-108. Agric Biol Chem 52:3009-3014

He Y, Keen JE, Westerman RB, Littledike ET, Kwang J (1996) Monoclonal antibodies for detection of the $\mathrm{H}: 7$ antigen of Escherichia coli. Appl Environ Microbiol 62:3325-3332

Jaradat ZW, Zawistowski J (1996) Production and characterization of monoclonal antibodies against the O-5 antigen of Salmonella typhimurium lipopolysaccharide. Appl Environ Microbiol 62:1-5

Jiravanichpaisal P, Miyazaki T (1994) Histopathology, biochemistry and pathogenicity of Vibrio harveyi infecting black tiger prawn Penaeus monodon. J Aquat Anim Health 6:27-35
Jory DE (1998) Use of probiotic on penaeid shrimp growout. Aquacult Mag 24:62-67

Jung TS, Thompson KD, Morris DJ, Adams A, Sneddon K (2001) The production and characterization of monoclonal antibodies against Photobacterium damselae spp. piscicida and initial observations using immunohistochemistry. J Fish Dis 24:67-77

Kiriratnikom J, Ruangsri J, Wanadet M, Songpradit A, Suanyuk N, Thapuksorn W, Supamattaya K (2000) The abiotic factors influencing the growth of luminescent bacteria, Vibrio harveyi in seawater. Songkla J Sci Technol 22:697-705

Köhler G, Milstein C (1975) Continuous cultures of fused cells secreting antibody of predefined specificity. Nature 256: 495-497

Köhler G, Milstein C (1976) Derivation of specific antibody producing tissue culture and tumor cell fusion. Eur $\mathrm{J}$ Immunol 6:511-519

Krieg NR, Holt JD (1984) Bergey's manual of systematic bacteriology, Vol 1. William \& Wilkins, Baltimore

Laemmli UK (1970) Cleavage of the structure proteins during the assembly of the head of T4. Nature 227:680-685

La Villa-Pitogo CR, Cecilia M, Baticados L, Cruz-Lacierda ER, de la Pena LD (1990) Occurrence of luminous bacterial disease of Penaeus monodon larvae in the Philippines. Aquaculture 91:1-13

Lee KK, Chen FR, Yu SR, Yang TI, Liu PC (1997a) Effects of extracelluar products of Vibrio alginolyticus on penaeid prawn plasma components. Lett Appl Microbiol 25:98-100

Lee KK, Liu PC, Kou GH, Chen SC (1997b) Passive immunization of the tiger prawn, Penaeus monodon, using rabbit antisera to Vibrio harveyi. Lett Appl Microbiol 25: 34-37

Lightner DV (1996) A handbook of pathology and diagnostic procedures for diseases of penaeid shrimp. World Aquaculture Society, Baton Rouge, LA

Liu PC, Lee KK, Chen SN (1996a) Pathogenicity of different isolates of Vibrio harveyi in tiger prawn, Penaeus monodon. Lett Appl Microbiol 22:413-416

Liu PC, Lee KK, Yii KC, Kou GH, Chen SN (1996b) Isolation of Vibrio harveyi from diseased Kuruma prawns Penaeus japonicus. Curr Microbiol 33:129-132

Liu PC, Lee KK, Tu CC, Chen SN (1997) Purification and characterzation of cysteine protease produced by pathogenic luminous Vibrio harveyi. Curr Microbiol 35:32-39

Moriarty DJW (1998) Control of luminous Vibrio species in penaeid aquaculture ponds. Aquaculture 164:351-358

Mosmann TR, Bauman R, Williamson AR (1979) Mutations affecting immunoglobulin light chain secretion by myeloma cells 1 . Functional analysis by cell fusion. Eur J Immunol 9:511-516

Munro J, Oakey J, Bromage E, Owen L (2003) Experimental bacteriophage-mediated virulence in strains of Vibrio harveyi. Dis Aquat Org 54:187-194

Okrend AJG, Rose BE, Matner R (1990) An improved screening method for the detection and isolation of Escherichia coli O157:H7 from meat, incorporating the 3M Petrifilm ${ }^{\mathrm{TM}}$ test kit-HEC-for hemorrhagic Escherichia coli O157:H7. J Food Prot 53:936-940

Pizzutto M, Hirst RG (1995) Classification of isolates of Vibrio harveyi virulent to Penaeus monodon larvae by protein profile analysis and M13 DNA fingerprinting. Dis Aquat Org 21:61-68

Quinlan JJ, Foegeding PM (1997) Monoclonal antibodies for use in detection of Bacillus and Clostridium spores. Appl Environ Microbiol 63:482-487

Ramesh A, Venugopalan VK (1987) Luminous microflora associated with the fishes Mugil cephalus and Tacho- 
monas vaginalis. Infect Immun 63:3388-3395

Ramesh A, Venugopalan VK (1989) Respone of enteric luminous bacteria to environmental conditions in the gut of the fish. J Appl Bacteriol 66:529-533

Rengpipat S, Phianphak W, Piyatiratitivorakul S, Menasveta P (1998) Effects of a probiotic bacterium on black tiger shrimp Penaeus monodon survival and growth. Aquaculture 167:301-313

Rivera-Betancourt M, Keen JE (2000) Murine monoclonal antibodies specific for lipopolysaccharide of Escherichia coli O26 and O111. Appl Environ Microbiol 66:4124-4127

Saha PK, Nair GB (1997) Production of monoclonal antibodies to the Non-Membrane-Damaging Cytotoxin (NMDCY) purified from Vibrio cholerae O26 and distribution of NMDCY among strains of Vibrio cholerae and other enteric bacteria determined by monoclonal-polyclonal sandwich Enzyme-linked Immunosorbent Assay. Infect Immun 65:801-805

Sithigorngul P, Chauychuwong P, Sithigorngul W, Longyant

Editorial responsibility: Timothy Flegel,

Bangkok, Thailand
S, Chaivisuthangkura P, Menasveta P (2000) Development of monoclonal antibody specific to yellow head virus (YHV) from Penaeus monodon. Dis Aquat Org 42:27-34

Sithigorngul P, Rukpratanporn S, Longyant S, Chaivisuthangkura P, Sithigorngul W, Menasveta P (2002) Monoclonal antibodies specific to yellow-head virus (YHV) of Penaeus monodon. Dis Aquat Org 49:71-76

Takeda T, Nair GB, Suzuki K, Shimonishi Y (1990) Production of a monoclonal antibody to Vibrio cholerae Non-O1 heatstable enterotoxin (ST) which is cross-reactive with Yersinia enterocolitica ST. Infect Immun 58:2755-2759

Zhang XH, Meaden PG, Austin B (2001) Duplication of hemolysin genes in a virulent isolate of Vibrio harveyi. Appl Environ Microbiol 67:3161-3167

Zorrilla I, Arijo S, Chabrillon M, Diaz P, Martinez-Manzanares E, Balebona MC, Moriñigo MA (2003) Vibrio species isolated from diseased farmed sole, Solea senegalensis (Kaup), and evaluation of the potential virulence role of their extracellular products. J Fish Dis 26:103-108

Submitted: May 3, 2004; Accepted: September 21, 2004 Proofs received from author(s): January 24, 2005 